\title{
The Impact of Supply Chain Integration and Internal Control on Financial Performance in the Jordanian Banking Sector
}

\author{
Miklós Pakurár ${ }^{1}$, Hossam Haddad ${ }^{2}$, János Nagy ${ }^{3}$, József Popp ${ }^{4, * \mathbb{C}}$ and Judit Oláh ${ }^{1} \mathbb{C}$ \\ 1 Institute of Applied Informatics and Logistics, Faculty of Economics and Business, University of Debrecen, \\ 4032 Debrecen, Hungary; pakurar.miklos@econ.unideb.hu (M.P.); olah.judit@econ.unideb.hu (J.O.) \\ 2 Károly Ihrig Doctoral School of Management and Business, University of Debrecen, 4032 Debrecen, \\ Hungary; hossam.haddad@econ.unideb.hu \\ 3 Oncology Institute, Faculty of Medicine, University of Debrecen, 4032 Debrecen, Hungary; \\ nagyjanos@unideb.hu \\ 4 Institute of Sectoral Economics and Methodology, Faculty of Economics and Business, University of \\ Debrecen, 4032 Debrecen, Hungary \\ * Correspondence: popp.jozsef@econ.unideb.hu; Tel.: +36-30-297-3163
}

Received: 28 December 2018; Accepted: 22 February 2019; Published: 27 February 2019

\begin{abstract}
The aim of this paper is to use a recently developed framework of supply chain integration (SCI) to examine the influence of a set of relationships between $\mathrm{SCI}$ and internal control on financial performance in the Jordanian banking sector. SCI consists of external integration and internal integration. External integration includes customer integration and supplier integration. This study utilizes survey data from 249 employees in the Jordanian banking sector and tests the research framework and hypotheses using exploratory factor analysis. The impact of supply chain internal and external integration and internal control significantly affected financial performance. The impact of the examined factors on financial performance is as follows, in decreasing order: internal integration, supplier integration, customer integration, and internal control. This study's contribution to supply chain management is in its integration of SCI and internal control variables to propose a practical framework for the banks to use, and its development of a measurement tool for managers to determine the effects of internal and external integration and internal control on financial performance.
\end{abstract}

Keywords: supply chain integration; customer integration; supplier integration; internal integration; internal control; financial performance

\section{Introduction}

In the 21st century, organizations have found themselves working in a rapidly changing environment characterized by vicious competition, globalization, competition between competitors, diversification, the rising expectations and demands of various customers, an emphasis on corporate social responsibility [1,2] and performance-related issues. In the light of this environmental reality, traditional management strategies and practices have become rather ineffective, and insufficient to outperform competitors and create more value [3]. Thus, researchers have argued as to why some organizations succeed while others fail. Following the emergence of the concept of supply chain management (SCM) at the beginning of the 1980s, it quickly attracted the attention of academics and professionals alike. In recent years, it has clearly proliferated in the literature on SCM in service and production. Supply chain management is defined as all those activities that are involved in and associated with the flow and transformation of goods from the extraction of the raw material stage 
to the end user, and the flow of information [4]. Turkulainen et al. [3] defined it as flows of services, products, finance, or information, from the source to the final customer [5].

SCM-related outcomes have received considerable attention from researchers, and a wide stream of published research has focused on the effects of SCM on supply chain integration [6,7], financial performance [8,9], and internal control [10]. In this respect, supply chain management is considered an effective strategy for organizations to improve their performance and boost competitiveness. Managers continue seeking organizational designs and attempting to develop integrations that allow for the support of SCI (supply chain integration) efforts for numerous purposes [3]. The integration process for customers and suppliers cannot be left out of internal integration, because it represents the basis for the development of both dimensions. Researchers have realized the importance of studying the three dimensions together (customer, supplier, and internal integration) and the impact of each dimension on performance.

The links between supply chain integration and financial performance have been widely investigated in the literature [8,9]; however, most existing research studies have focused on investigating the effects of SCI on business performance and financial performance. Very few studies have investigated the effects of $\mathrm{SCI}$ on the financial performance of banking sectors.

Since 1992, the Committee of Sponsoring Organizations of the Treadway Commission (COSO) has been developing a framework to evaluate internal control in organizations. These procedures are affected by a board of directors, management, and other personnel. The committee intends to provide reasonable assurance regarding the achievement of the following objectives: the effectiveness and efficiency of operations, the reliability of financial reporting, and compliance with applicable laws and regulations [11].

There are five components to support the performance of an organization's vision, mission, strategies, and the related objectives of the business: control of the environment, risk assessment, control of activities, quality of information, and monitoring. These components work together to enhance the establishment of internal control within organizations through directed leadership and shared values and a culture that emphasizes accountability for control [10].

The authors' motivation for this topic is that the literature does not deal with the topic in detail; in fact, previous studies have not addressed the importance of supply chain integration in the Jordanian banking sector. Finally, we draw on the concept of supply chain integration in the banking sector to advise banks that they should develop a comprehensive framework of integration along their supply chain partners. The SCI literature first appeared in relation to production, and after that, it was introduced in services. The novelty of this paper is that it is a new contribution applying a supply chain integration theory to the banking sector. This study suggests that banks should increase their efficiency levels while improving their integration policy. The aim of our research is not only to prove that higher integration leads to higher bank performance, but also to determine what factors are involved in integration, resulting in a better bank performance in Jordan.

\section{Literature Review}

\subsection{Supply Chain Management Practices}

According to de Souza Miguel and Brito [12], the evolution of the SCM concept includes a process integration view and a strategic view. The process integration view refers to the coordination between SC supply chain partners in the business activities that enhance customer satisfaction. On the other hand, the strategic view refers to the assignment of organizational resources and members' efforts to create a supply chain SC strategy that improves competitive advantage by lowering costs and enhancing customer satisfaction. Table 1 summarizes the SCM practices that have been used in these well-cited articles. 
Table 1. Summary of previous literature used to define supply chain management (SCM) practices.

\begin{tabular}{|c|c|}
\hline SCM Practices & References \\
\hline Customer integration & $\begin{array}{c}\text { Abdallah et al. [13], Flynn et al. [6], Jabbour et al. [14], Lotfi et al. [15], } \\
\text { Wong et al. [16], Slusarczyk et al. [17], Lii and Kuo [18] }\end{array}$ \\
\hline Supplier integration & $\begin{array}{c}\text { Abdallah et al. [13], Flynn et al. [6], Jabbour et al. [14], Lotfi et al. [15], } \\
\text { Wong et al. [16], Lii and Kuo [18] }\end{array}$ \\
\hline Internal integration & $\begin{array}{c}\text { Abdallah et al. [13]; Flynn et al. [6], Jabbour et al. [14], Lotfi et al. [15], } \\
\text { Wong et al. [16], Lii and Kuo [18] }\end{array}$ \\
\hline Postponement & Abdallah et al. [13], Jabbour et al. [14] \\
\hline Continuous process flow & Flynn et al. [6] \\
\hline $\begin{array}{l}\text { Information sharing } \\
\text { Lean }\end{array}$ & $\begin{array}{c}\text { Abdallah et al. [13], Flynn et al. [6], Jabbour et al. [14], } \\
\text { Qi et al. [19] }\end{array}$ \\
\hline
\end{tabular}

Source: Authors' own editing, 2018.

SCM has been investigated in the context of several practices. For instance, [20] conducted a study based on the five practices of supplier integration, customer integration, internal integration, information sharing, and total quality management. Finally, many researchers, as shown in Table 1, used five SCM practices: supplier integration, internal integration, customer integration, information sharing, and postponement. Consequently, three SCI categories were used in this study, based on their prevalence in previous studies: supplier integration, customer integration, and internal integration.

\subsection{Supply Chain Integration}

Flynn et al. [6] argued that supply chain integration implies collaboration among industrialists and other supply chain partners in order to develop an effective and efficient movement of materials, resources, parts, and information to produce products and services that are valuable to the customer quickly and at low cost. Qi et al. [19] defined supply chain integration as cooperation plans and activities between suppliers, manufacturers, warehouses distributors, and retailers that aim to develop products by transforming raw materials into finished goods for customers.

An extensive review of the supply chain integration literature focused on the dimensions of customer integration, supplier integration, and internal integration, which integrates all potentials, strategies, and effective processes and practices into cooperative and synchronized processes to fulfill customer needs [6]. Two major classifications of supply chain integration are external integration, which includes customers and suppliers, and internal integration $[13,18]$.

Most supply chain integration studies have focused on the exchanging of commodities and the flow of information more than on financial procedures or the flow of cash [21]. From a financial perspective, the cash flow from one organization to another includes expenses, investment, receipts, and in addition, the processes with partners that demonstrate that the financial supply chain operates in parallel with the physical supply chain. Regardless of the type of products, services, or information flow, payment is considered intrinsic to the financing of production and trade. Thus, the financial supply chain is commonly included in all supply chains.

$\mathrm{SCI}$ is an effective method that enhances the performance of an organization's suppliers and customers [6] and facilitates external and internal business functions. Moreover, [22] highlighted the importance of SCI as a means to reduce the costs of controlling economic exchanges and transactions between partners and preventing opportunistic behavior, which is a consequence of others' interests.

\subsubsection{Supplier Integration}

Kim [23] defined supplier integration as "an organizational process of buying firms and suppliers sharing and applying operational, financial, and strategic knowledge in order to generate mutual benefits."

Regardless of the differences in terminology that have been used to measure supplier integration, the main purpose of supplier integration is to exceed a single organization's limits so as to coordinate 
processes easily. Flynn et al. [6] and Kim [23] described a supply chain integration measurement model that was designed to measure the degree of supplier and customer integration. These two elements are very important areas of the supply chain; information sharing, for instance, is the interchange of information between the partners. External integration is how closely an organization works with its partners (suppliers and customers).

Danese [24] considered the relevant areas of supplier integration to be information sharing between the company and its suppliers' production plans, quality, and design, and direct quality improvement programs. Supplier integration seeks to achieve a smooth, efficient flow of materials within the supplier network, and prevent potential obstacles in the process of procurement and production.

The sharing of information with suppliers creates greater confidence while reducing dysfunctional conflicts between buyers and suppliers and allowing for effective communication. Danese [24] stated that with supply chain and supplier integration, buyers and suppliers can exchange knowledge and information and develop the relationships that are required to manage materials and the flow of information collaboratively and improve procurement and production.

The management and development of the relationship is considered a strategic part of the supplier integration process. de Souza Miguel and Brito [12] argued that the benefit of constructing long-term relationships with suppliers is that it reduces the cost of the transaction through trust and reputation building [25]. Supplier integration consists of the interchange of information, knowledge, and materials in different directions.

There is no particular form that supplier partnerships must take; they can be flexible and could be modified according to the objective of the partnership. Due to the cooperation and coordination among organizations, wasted effort and time can be reduced or eliminated [24]. In this respect, many researchers have demonstrated the fundamental role of supplier integration in differentiating organizations by creating competitive advantage and improving the whole supply chain performance $[6,13,14]$.

\subsubsection{Customer Integration}

Lau et al. [26] stated that the only individual who can make a decision and have the ability to evaluate a product is the customer, because the customer has potential purchasing power, and as such is a decision maker from a marketing point of view. Moreover, information sharing on the basis of interactions between the customers and the organization enhances customer integration. Additionally, the relationships between customers and an organization enable the organization to raise its level of competence [6].

Another definition of customer integration according to Kim [23] is the organizational practices of identifying, explaining, and using customers to produce specific products according to their needs and in doing so maximize their expectations and satisfaction. Lau et al. [26] shed light on information sharing through customer integration between customers and the organization itself. The feedback obtained by organizations from their customers provides them with all the information associated with operations such as inventory. A solid relationship with customers will be useful to enhance supply chain programs.

Lotfi et al. [15] highlighted that customer integration involved customers' opinions being included in the production process, by making the relationship between the customer and the manufacturer much easier. Knowing clearly the organization's goals, intentions, and strategy can reduce uncertainty in the minds of customers. Nevertheless, the advantage of clarity might be outweighed by the loss of closeness and flexibility in highly formalized structure types [27].

If design-integrative efforts are not up to date, based on customer requirements and opportunities, they are likely to create solutions that may be internally efficient yet externally unproductive. Ataseven and Nair [9] have found that customer integration has a positive relation with financial performance. Customer integration alone is not enough for the full development of greater business performance 
capabilities. Noticeably, specific needs arising from well-functioning contacts and strategic alliances with customers may be of limited value if a business is not capable of adjusting products and process specifications to meet those needs [28].

\subsubsection{Internal Integration}

According to Kim [23], internal integration can be defined as all the practices of merging together and developing the internal resources and information to generate a shared knowledge that goes beyond the boundaries of individual functions or sections, and through doing so help external integration and achieve goals. Furthermore, the efficient collaboration between the manufacturer and suppliers that is achieved through processes, activities, and strategies in order to satisfy customer needs is called internal integration [6]. Joint planning, functional collaboration, information sharing, and teamwork boost the performance of organizations and their internal integration in order to ensure customers' expectations can be met and deliveries are on time.

Internal integration means forming a long-term plan linking processes and practices into organized and synchronized processes to meet customer needs and preferences and transact efficiently with suppliers [29]. The aim of internal integration is to smooth the movement of resources, money, product, and information to satisfy customers quickly and at low cost [6].

Lotfi et al. [15] argued that internal integration is the integration among the departments and processes inside the organization to satisfy and meet customer needs. Internal integration is the coordination between departments and functions, creating an integrated system in order to satisfy the expectations and needs of customers, as well as boost performance. More attention needs to be paid to cooperation among functional departments, such as inventory, sales, and distribution [15].

Ayoub et al. [30] noted that internal integration is a mix of various departments and starts with raw materials and converting processes, and continues up to distribution. Abdallah et al. [13] stated that the most important factor that affects a supply chain positively is internal integration. To go even further, internal integration relies on cooperation among the departments and functions of an organization, which creates value through cooperation.

Complex organizations are composed of many varied, interconnected parts. Complexity hinders the capability of organization members to identify and take action in relation to issues of strategic significance. Information barriers and unusually narrow-minded interests are all possible negative effects of structural complexity, and they present significant challenges to the quest to achieve alliances, knowledge sharing, and agreement in decision-making [27].

Managers who have a wide range of experience and skills are better prepared to work across functional and departmental lines. The exposure to various functions inside an organization that managers obtain from structural processes, such as job rotation, is a significant facilitating factor for internal integration. A manager who gains experience within a broad set of organizational units is in a better position to cooperate with personnel from any organizational unit. Such a manager understands the barriers impeding communication and collaboration internally and externally.

\subsection{Internal Control}

In 1992, COSO's internal control-integrated framework became one of the most widely accepted internal control frameworks in the world. The framework states that internal control differs according to the context, industry, and nature of the business. Internal control may cause conflict if not clearly defined, especially when it is built into law, regulations, or rules. Internal control is extensively characterized as a procedure that is affected by the board of directors, management, and other personnel [11].

Generally, banks set up internal control systems to identify and oversee risks. They are utilized to reinforce risk management systems. All banks ought to have individual internal control systems that are capable of providing an assurance that risks are managed in an effective way. Therefore, the objective of an effective internal control system is to provide an assurance that a bank is efficiently 
and effectively directing its operations according to its mission statement, that its management data and financial reporting are dependable, and that it advances in compliance with applicable laws and regulations. If a bank does not have a viable internal control system, it is conceivable that it could be vulnerable [31]. Internal control is now linked to risk management. Internal control should cover the identification and mitigation of risks; the new conceptualization of internal controls is that they exist to assist the organization in managing its risks and promote effective governance processes [10].

Pallant [32] reported on internal control called the Internal Control-Integrated Framework, which is referred to as "COSO". The framework classifies an organization's internal control system into five integrated components, which should be built into business forms over the whole organization so as to accomplish its goals. These are derived from the way that management runs a business, and are integrated with the management process. The components are control environment, risk assessment, control activities, information and communication, and monitoring activities.

According to Ayagre et al. [33], the internal control components and business processes must collaborate continuously for a sound, effective internal control framework. The consistent and collaborative interaction of an internal control system with business procedures is essential for the effectiveness of an internal control framework. Control goals and measures that are derived from the monitoring and assessment of risks must be integrated into operational business units and business practices through effective data. Furthermore, it is necessary to communicate across the organization the control component that guarantees that a smooth stream of data reaches the work force that is in charge of internal controls [34].

\subsection{Performance and Financial Performance}

Performance is considered an outcome of all the operations and strategic activities that are conducted for the organization [35]. Organizations are more concerned about measuring performance precisely for accounting objectives. In order to develop plans and evaluate their completion, performance measurement is needed.

Huo [36] highlighted that for organizations, financial performance has to be the major measure of supply chain performance, because it maximizes shareholder profit. The literature has adopted two main approaches to the measurement of financial performance. The first approach is subjective measurements, in which the measurement of performance is based on the evaluation and expectations of respondents or their comparison with competitors. The second is objective, which uses absolute measurements of performance, such as financial ratios [37].

The performance concept is a complicated issue, as [36] argued that qualitative and quantitative concepts are comprehensive and broader than the performance concept. However, [6] mentioned the limitations of relying solely on financial criteria for performance. Several authors have focused on the benefits associated with a supply chain integration that includes efficiency, quality, delivery, and flexibility as aspects of operational performance $[9,19]$. From a theoretical point of view, most of the studies $[8,9]$ and $[6,38]$ on supply chain management show that there is a significant relationship between supply chain integration and performance. In particular, [38] provided evidence that "the direct relationship of supply chain integration to financial performance is non-significant".

\subsection{The Banking Sector in Jordan}

Recently, the Jordanian banking sector has witnessed important developments. These developments are mainly attributable to the Central Bank of Jordan (CBJ). By implementing the newest financial practices and sophisticated supervisory and regulatory activities, the performance of the banking sector in Jordan has been developed and upgraded.

The banking sector has a vital role in Jordan in driving the economy by motivating national savings and using them to finance the various economic sectors. According to the CBJ report for 2017, the banking sector's contribution to gross domestic product (GDP) was 18.7\%. Banks leverage branch 
networks to provide clients with comprehensive financial solutions that are supported by the latest digital banking services.

Banks also continue to enhance operational efficiency and business processes whilst maintaining prudent credit policies and efficient risk management platforms. In the Jordanian banking classification, there are three types of banks: commercial, Islamic, and foreign. There are 16 commercial banks, four Islamic banks, and nine foreign banks. Islamic banking represents the system of natural processes or business transactions that take place according to the values and principles of Islam, which are called "Sharia". An Islamic bank cannot finance products or services that are prohibited by Islamic law.

Beyond the literature, the importance of the banking sector in Jordan has been considered one of the main sources that contribute to GDP; moreover, it is the engine and a major supporter of the economy in Jordan. Nowadays, banks pay more attention to the effective functioning of the banking sector in order to achieve the essential goal of financial reforms.

Profitability and efficiency have also become one of the challenges faced by banks to strengthen their financial positions in order to meet the risks associated with openness and globalization. This study would help banks improve their internal and external processes by developing integration to make their financial performance better.

\section{Conceptual Model and Research Hypotheses}

\subsection{Conceptual Model}

The model in Figure 1 describes how the dimensions of supply chain integration and internal control affect financial performance $[9,39],[6,10,13,38,40]$.

\section{Independent variables}

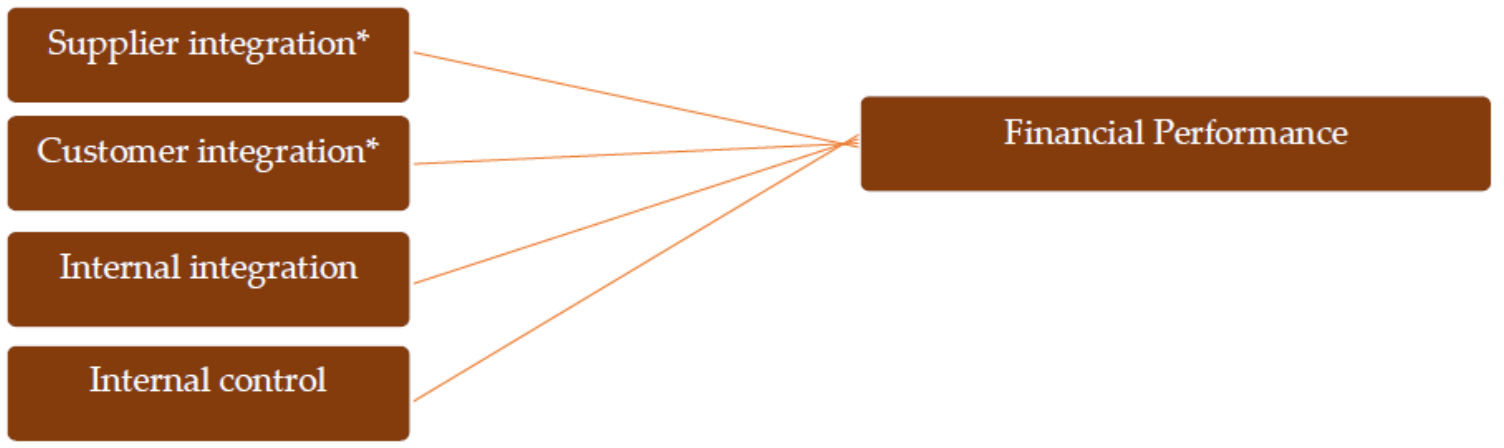

Dependent variable

Figure 1. Supply chain integration and financial performance. ${ }^{*}$ External integration consists of supplier integration and customer integration. Source: Authors' own editing, 2018.

Moreover, it shows a bank's customers and competitors' orientation, including the relationships between supply chain integration and internal control and financial performance. This study has adopted one perspective of Figure 1, showing the bank's point of view regarding supply chain integration and financial performance.

\subsection{Hypotheses Development}

Mele et al. [41] stated that there is a network within inter-organizational processes. This is evidence that a new development process is not only a chain of intra-organizational activities, but also a combination of information and resources. In order to create value for the entity, integration becomes essential; the organization acts as a partner with its external entities to set up strategies, procedures, and behaviors into collaborative, synchronized, and manageable processes [42]. 
Schoenherr and Swink [8] argued that financial performance is a critical factor in supply chain integration, and affects profits by driving processes and efficiencies in order to make decisions and improve the strategy to solve problems. Other researchers have also found that supply chain integration significantly assists financial performance [39,42,43]. Moreover, [44] stated that an organization should invest resources to develop trust with customers and suppliers in order to achieve better financial performance.

In their recent empirical investigation, [9] studied internal integration and supplier integration with customers, showing that both customers and suppliers have a significant impact on financial performance. Flynn et al. [6] indicated that internal and customer integration are strongly related to improving performance, more so than the supplier dimension. Yu et al. [45] stated that supplier integration is positively related to financial performance.

Ataseven and Nair [9] pointed out that suppliers were considered providers of raw materials and products, which is not enough: they should be important partners in the interaction and flow of skills, information, and knowledge. Internal integration is integration between the internal functions of an organization by coordinating and utilizing internal resources [16]. Silvestro and Lustrato [21] found that banks could support and help buyers and suppliers develop a more holistic understanding of supply chain integration, synchronization, and performance. The financial supply chain runs parallel to the flow of goods and information. Based on a literature review, the results identified a number of successes.

Chang et al. [39] argued that customers and suppliers are the most important sources for improving financial performance. Msimangira and Venkatraman [46] pointed out that decision-makers should consider costs, benefits, and risks in the market environment before adopting a strategy. Wong et al. [16] mentioned that the extent to which customers and manufacturers coordinate decisions is related to inventory level, production planning, demand forecasting, order tracking, and product delivery combined reflect customer integration. Msimangira and Venkatraman [46] stated that supply chain strategies can be evaluated in light of an organization's market, whereas practices and strategies are not only dependent on the nature of the business, the environment, and technology, but also on the relationship between supply chain integration, diversification, and financial performance. Thus, supplier integration, customer integration, and internal integration are expected to have significant impacts on financial performance.

\subsubsection{The Effect of Supply Chain Integration on Financial Performance}

Huo [36] stated that the organizational capability theory and the capabilities of supply chain integration are the key factors in organizational performance. In order to improve efficiency and effectiveness, the integrative capabilities, whether external or internal, should be considered as an approach. The roles of supply chain integration in achieving positive relationships on financial performance have recently been discussed $[6,23,47,48]$. To achieve a high level of performance, the organization has to have the widest degree of arcs of integration [8]. The impact of customer integration on financial performance is inconsistent; Koufteros et al. found positive effects of customer integration on financial performance [27], while [6] could not find a positive relationship between customer integration and financial performance. We propose that internal and external integration contributes to a bank's financial performance, leading to the following hypotheses:

Hypothesis 1: Supplier integration positively influences financial performance.

Hypothesis 2: Customer integration positively influences financial performance.

Hypothesis 3: Internal integration positively influences financial performance. 


\subsubsection{Internal Control and Financial Performance}

Hannah [49] stated that in order to enhance the reliability of financial performance, there must be a regulatory framework that is similar to internal control systems, including direct or indirect internal audits, in order to increase the transparency and accountability among information providers in the organization. According to Brunswicker and Chesbrough [50], internal control has problems associated with lower revenues. Due to this, we should explore the links between the disclosure of material weakness and fraud. Internal control provides an independent appraisal of the quality of managerial performance as regards their ability to carry out the assigned responsibilities for better revenue generation. Werner and Gehrke [51] mentioned that an effective internal control system is linked with organizational success in terms of achieving revenue targets [52]. Effective internal control involves revising the controls that are employed to protect assets, with a continuous review of the reliability and integrity of financial information, and an assessment of compliance policies, procedures, and applicable laws and regulations. Organizations have a responsibility to train, educate, and sensitize their employees to use internal control systems. The effectiveness of internal control is based on the skills, competency, and transparency of the people that use it.

There are two types of internal controls: preventive and detective. Preventive controls predict problems before they occur, find a solution, make amendments, and prevent errors and acts of omission from occurring. Detective controls are used to reveal and report the occurrence of an omission, an error, or a malicious action or act, in order to minimize the threat, identify the cause of the problem, and correct the defective controls by correcting the problems when discovered.

\section{Hypothesis 4: Internal control positively influences financial performance.}

\subsection{Supply Chain Integration and Internal Control}

\subsubsection{Independent Variables}

Supply chain integration refers to a firm's combination of internal functions and the collaboration between the manufacturer, its suppliers, and customers in order to enhance its competitiveness $[6,18]$. Integrated systems have a number of advantages and characteristics that are shaped by relying on a number of departments within an organization. The suppliers, customers, and internal departments, as well as the internal control, should be taken into consideration, whether inside or outside the organization, in order to provide valuable services to customers. Based on the literature review, a questionnaire was developed with 34 questions (see Supplementary Materials).

Customer integration refers to building long-term relationships with customers to obtain information about the market, technology, and creating products that meet customer requirements and enhance their satisfaction [15]. Banks have to respond to customers' needs and wants by building a long-term relationship with the management to improve customer satisfaction, manage complaints and feedback, meet customer expectations, and create a sense of fair play with customers.

Supplier integration refers to building long-term and strong relationships with suppliers to reinforce functional capabilities to attain an ongoing benefit [53]. The organization should be able to manage, develop, and maintain relationships with its suppliers for the long run by managing materials and the flow of information collaboratively, and improving procurement and production. Managing and developing the relationship is considered a strategic part of the supplier integration process.

Internal integration is the level to which a company integrates and connects its internal departments, teams, and information to cooperate effectively and improve performance, competitiveness, and customer satisfaction [6,15,42]. Internal integration influences an organization's ability to structure its own organizational strategies according to the existing collaborative practices and processes, satisfy customer needs and wants, achieve competitive consistent integration within an organization, achieve competitive advantage, have interactive functions among departments, and establish procedures for conflict resolution and information sharing. 
Internal control is extensively characterized as a procedure that is affected by the board of directors, management, and other personnel [11]. It is intended to provide reasonable assurance as regards the achievement of the following objectives: effectiveness and efficiency of operations; reliability of financial reporting, and compliance with applicable laws and regulations.

For the measurement of the effects of independent variables, a questionnaire was constructed with the following numbers of questions: eight for customer integration, eight for supplier integration, 10 for internal integration, and eight for internal control.

\subsubsection{Dependent Variable}

Financial performance is the most important measure of success for banks. In this study, subjective measurements were used, meaning that bank managers answered questions about financial performance. Questionnaires were used because this method is common in the literature, did not require the respondents to identify their banks, and the bank managers questioned had enough knowledge and experience to judge the financial performance of their banks. Investors and lenders need financial information that is relevant, reliable, and comparable across borders. Firm performance refers to how well a firm fulfills its financial goals compared with the firm's primary competitors. In the questionnaire, six questions are related to financial performance.

\section{Material and Methods}

\subsection{Questionnaire Design}

The questionnaire consisted of three parts. The first part involved the covering letter, in which the research goals were explained. The covering letter included the assurance that responses would be treated confidentially. The second part included questions related to demographic data. Finally, the third part included all the statements that measured the independent and dependent variables. A five-point Likert scale was applied for the variables. The data collected from participants was coded and further processed with an Excel database. All of the data was analyzed using the Statistical Package for Social Science (SPSS) software program.

The study instrument in its final form was intended for managers from internal audit, operations, risk management, information technology, compliance, development of services and products, and logistic departments in Jordanian banks.

\subsection{Research Population and Sample}

A descriptive research design was used to provide a summary of the data, and describe the characteristics of the variables [54]. A correlation design was applied to measure the strength of the investigated relationship between variables. Books, annual reports of the banks, periodicals, journals, references, and the Internet, as secondary sources, were used to collect the required data. The survey, as a primary source, was used to collect the relevant data to study the impact of supply chain integration and internal control on financial performance.

The questionnaires were distributed to and collected from all types of Jordanian banks in the year 2018. There are three types of banks in Jordan: commercial banks, Islamic banks, and foreign banks. Of the 309 respondents received, 60 were rejected due to missing data. Thus, 249 respondents were accepted for data analysis.

The sample consisted of 249 respondents working in departments in Jordanian banks in positions related to internal control, product development, procurement, compliance, risk management, and operations. The proper sample size was determined to reflect the respondents' opinions [54].

The questionnaire was designed for the mangers of the banks; it was written in Arabic and in English, distributed by hand, and also made available on Google drive. 


\subsection{Techniques for Data Analysis}

Our design was examined by using exploratory factor analyses to measure the relationships between variables and develop a measurement tool for managers to determine the effect of internal and external integration and internal control on financial performance.

In the pilot study, 41 bank managers filled in the questionnaire, and after this, the respondents were required to give their perceptions and opinions of their banks in relation to supply chain and internal control on financial performance.

Cronbach's alpha coefficient was used to assess the reliability of the measurement scales. All of the alpha values were greater than 0.70 , and the highest value of internal integration was 0.937 . Table 2 shows the reliability for the supply chain integration and internal control on financial performance.

Table 2. Reliability of the scale's variables.

\begin{tabular}{ccc}
\hline Variables & Number of Items & Cronbach Alpha \\
\hline Independent variable & 34 & 0.969 \\
Customer integration & 8 & 0.902 \\
Supplier integration & 8 & 0.921 \\
Internal integration & 10 & 0.937 \\
Internal control & 8 & 0.885 \\
Dependent variable & 6 & 0.887 \\
Financial performance & 6 & 0.887 \\
Overall & 40 & 0.975 \\
Overall average & 5 & 0.946 \\
\hline
\end{tabular}

Source: Authors' own editing, 2018.

\section{Results and Discussion}

\subsection{Results}

5.1.1. The Relationship between Supply Chain Integration, Internal Control, and Financial Performance

First, the correlation was tested between the dependent variable-financial performance-and the independent variables-external integration (customer integration, supplier integration), internal integration, and internal control—using Spearman's non-parametric test, certain assumptions about the distribution of values in a sample, and then a parametric test.

Basic forms of correlation coefficients (e.g., Spearman rho, Pearson) were calculated to examine the strength and direction of the relationship between each set of variables.

The correlation shows that all eight items for customer integration are significantly, as well as positively, associated with the dependent variable financial performance. The statistical results illustrate that there are significant correlations $(\mathrm{r})$ between the variables in customer integration question number one $(r=0.468)$, which scored the lowest, and customer integration question number six $(r=0.661)$, which scored the highest.

The eight items for supplier integration items are significantly positively associated with the dependent variable: financial performance. The statistical results indicate that there are significant correlations between the variables in supplier integration question seven $(r=0.456)$ which scored the lowest, and supplier integration questions one and six $(r=0.660)$, which scored the highest.

The correlation shows that all 10 internal integration items are significantly, as well as positively, associated with the dependent variable financial performance. The statistical results indicate that there are significant correlations between the variables in internal integration question six $(r=0.575)$, which scored the lowest, and internal integration question eight $(\mathrm{r}=0.740)$, which scored the highest.

The correlation shows that all eight items for internal control items are significantly and positively associated with the dependent variable of financial performance. The statistical results indicate that 
there are significant correlations between the variables in internal control question three $(r=0.398)$ which scored the lowest, and internal control question eight $(r=0.740)$, which scored the highest. We can observe that all the above tested correlations were significant at the $p<0.0005$ level. All these items can be used in a large factor analysis.

\subsubsection{Exploring the Structure of Items}

Factor analysis was conducted to assess the underlying structure for the multiple items of the research variables. In the first analysis, we can find that there are five factors with eigenvalues above one. The items mostly lie on one dimension, where we can decide between one and five according to a number of factors. On the basis of a scree plot, we would decide on one component, but on the basis of an original group of questions and literature, we try to build a model of a four-principle component.

Based on the component analysis performed, we can say that $56 \%$ of the variance associated with question one is a common, or shared variance. Another way to look at these communalities is in terms of the proportion of the retained factors represented by the communalities after extraction. The highest communalities have been found at internal integration question nine from the internal integration scale with extraction at $79.4 \%$ of the variance, while the lowest communalities have been found at internal control seven from the internal control scale with extraction at $54.1 \%$ of the variance. Initial communalities are estimated for the variance in each variable, which is accounted for by all the components or factors. Extraction communalities are evaluated for the variance in each variable that is accounted for by the factors (or components) in the factor solution. Small values indicate variables that do not fit well with the factor solution, and should possibly be dropped from the analysis.

\subsubsection{Promax Rotation}

We applied the Promax rotation, which is an oblique one, so it allows factors to be correlated. All the communalities were large enough to continue the analysis (the rule of thumb is that they should be above 0.25 ). The highest communalities were found with internal integration question nine from the internal integration scale, which had extraction at $76 \%$ of the variance, while the lowest communalities was found with supplier integration question seven from the supplier integration scale, which had extraction at $43.3 \%$ of the variance.

Using oblique Promax rotation, we decided to utilize four components in order to prove the four groups of questions in the literature that have been mentioned above. In addition, we eliminated some items to prevent cross-loading, and moved some items from their original subscale to another, in accordance with the result of the analysis. The rotated solution showed that internal control items one and eight belong to the integration subscale, while customer integration items one and internal integration three belong to the supplier integration subscale, showing that several items must have been removed (customer integration items five and eight, supplier integration items one and eight, internal control item four, and internal integration items one and two).

The top communalities were found for customer integration item two from the internal integration scale, with extraction at $78.9 \%$ of the variance, while the low communalities were found at internal control item seven from the internal control scale, with the extraction at $53.3 \%$ of the variance. All the previous communalities are large enough to continue the analysis (the rule of thumb is that it should be above 0.25).

The percentage of total variance was extracted for each component, and altogether, it was $66.678 \%$; the first component explained $11.25 \%$ of the variance, the second variance explained $10.719 \%$, the third factor explained $7.297 \%$ of the variance, and the fourth factor explained $9.443 \%$.

The pattern matrix reveals that in the final solution, factor one consists of nine items. This factor was labeled 'internal integration', and demonstrated a high internal consistency, which will show when we examine the reliability test later. The second factor consisted of seven items including five items from supplier integration, one item from customer integration, and one item from internal integration. This factor was identified as "supplier integration" and reflected a high internal consistency, as we 
will examine in the reliability test later. Factor three contained five items relating to control, and was labeled "internal control". The internal consistency of this item was also high, as we will examine in the reliability test later. The fourth factor was made up of five items, all of which were related to customers. This factor was called "customer integration", and was found to be highly reliable. Overall, the factor analysis of the items revealed that from all of the items with the same response scale, only seven items did not belong to any factor. For the purposes of further analysis, these four factors were considered subscales of supply chain integration and internal control in Jordanian banks. The factor loadings are appropriate, and there is no cross-loading. The rotated solution showed that internal control items one and eight belong to the internal integration subscale, while customer integration item one and internal integration item three belong to the supplier integration subscale.

\subsubsection{Reliability Test}

Garson [55] stated that "Cronbach's alpha is commonly used to establish internal consistency in constructing validity, with 0.60 considered acceptable for exploratory purposes, 0.70 considered adequate for confirmatory purposes, and 0.80 considered good for confirmatory purposes". The derived factors in each construct were tested for reliability to emphasize their internal consistency. The Cronbach's alpha values ranged from 0.773 to 0.943 . The general Cronbach's alpha value of all the extracted factors was 0.967 . This means that there is also a high-level of consistency in the structure of the data. All of the values for Cronbach's alpha were above the acceptable level of 0.60 .

Cronbach's alpha $(\alpha)$ is the most widely used test to measure the internal reliability of a scale [56]. The range of $\alpha$ is from zero to one. Hence, the higher $\alpha$ is, the more reliable the scale. There are wide differences amongst researchers and authors regarding what value of $\alpha$ should be considered acceptable. However, in social science studies, a value of 0.60 is acceptable for hypothesis testing [54].

The general $\alpha$ of this study's scale was 0.9650 , which is very high. Table 3 summarizes the value of the four composite scales in this study; all of them were good, and above the lowest level of accepted reliability in the social sciences $(0.60)$.

Table 3. Reliability of the variables (Cronbach's alpha).

\begin{tabular}{ccccc}
\hline Variables & $\begin{array}{c}\text { Original Number } \\
\text { of Items }\end{array}$ & $\begin{array}{c}\text { Items after } \\
\text { Deletion }\end{array}$ & $\begin{array}{c}\text { Cronbach's } \\
\text { Alpha }\end{array}$ & $\begin{array}{c}\text { Final Number } \\
\text { of Items }\end{array}$ \\
\hline Internal integration (II) & 10 & 8 & 0.934 & 9 \\
Supplier integration (SI) & 8 & 6 & 0.910 & 8 \\
Customer integration (CI) & 8 & 6 & 0.872 & 5 \\
Internal control (IC) & 8 & 7 & 0.858 & 5 \\
Total/overall Cronbach's & 34 & 27 & 0.848 & 27 \\
\hline
\end{tabular}

Source: Authors' own editing, 2018.

Here, we have to examine the reliability of the 34 original items, which after rotation become 27 . The overall value of the new subscale score of Cronbach's alpha of reliability is 0.848 . The subscale of internal integration originally consisted of 10 items, but two of them were deleted (internal integration item one and two); furthermore, during the factor analysis, because of cross-loading, two other items were included (internal control items one and eight). The final score of Cronbach's alpha of reliability is 0.934 . The subscale of supplier integration originally consisted of eight items, but two (supplier integration items one and eight) were deleted, and two from another subscale were included (customer integration item one, internal integration item three), which were moved during the factor analysis because of cross-loading. The final score of Cronbach's alpha of reliability is 0.910 . The subscale of internal control originally consisted of eight items, but one of them was deleted (internal control item four) during the factor analysis due to cross-loading. The final score of Cronbach's alpha of reliability is 0.858 . The subscale of customer integration originally consisted of eight items, but two of them were 
deleted (customer integration items one and eight) during the factor analysis because of cross-loading. The final score of Cronbach's alpha of reliability was 0.872 .

The correlations between these factors and supply chain integration and internal control did not exceed 0.80 , showing that all correlations are significant at the 0.01 level. Therefore, it can be concluded that the supply chain integration and internal control construct has a considerable level of discriminant validity. In addition, there is no evidence of multicollinearity.

\subsubsection{The New Model after Rotation}

The new subscales for financial performance after rotation are illustrated in Figure 2. Internal integration comes first in the model, second is supplier integration, internal control comes third, and the last subscale is customer integration.

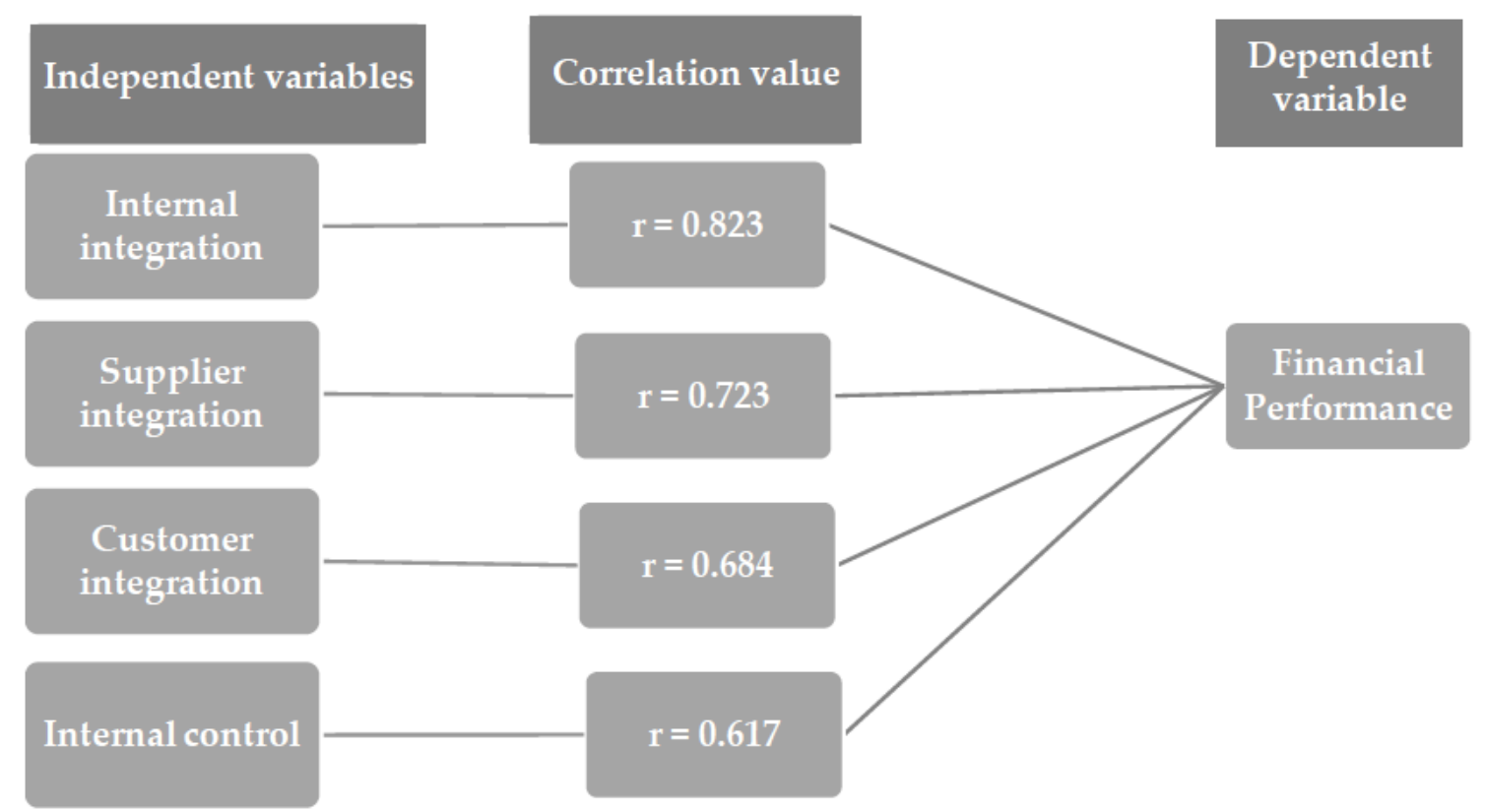

Figure 2. New subscale for supply chain integration (SCI) and internal control. Source: Authors' own editing, 2018.

The results of exploratory factor analysis (EFA) - with a few modifications-confirmed the existence of four subscales (customer integration, supplier integration, internal integration, and internal control) that we originally supposed influenced financial performance.

To check these hypotheses, we tested the correlations between the dependent variable, financial performance, and the new independent variable factors after rotation.

Table 4 shows that the correlations of dependent variables and independent variables are as follows, in decreasing order of r-values.

The first principal factor affecting financial performance is internal integration (H2). The correlation shows that the internal integration subscale is significantly positively associated with the dependent variable financial performance $(r=0.823)$.

The second principal factor affecting financial performance is supplier integration (H1b). The correlation shows that the supplier integration subscale is significantly positively associated with the dependent variable financial performance $(r=0.723)$.

The third principal factor affecting financial performance is customer integration (H1a). The correlations in Table 4 show that the customer integration subscale is significantly and positively associated with the dependent variable financial performance $(r=0.684)$. 
The fourth principal factor affecting financial performance is internal control (H3). The correlation shows that the internal control subscale is significantly positively associated with the dependent variable financial performance $(\mathrm{r}=0.617)$.

All the above-tested correlations were significant at a $p<0.0005$ level when they were observed. The statistical results indicate that all of the research hypotheses are true. The order of the principal components based on the measure of correlation is: internal integration, supplier integration, customer integration, and internal control.

Table 4. Correlations.

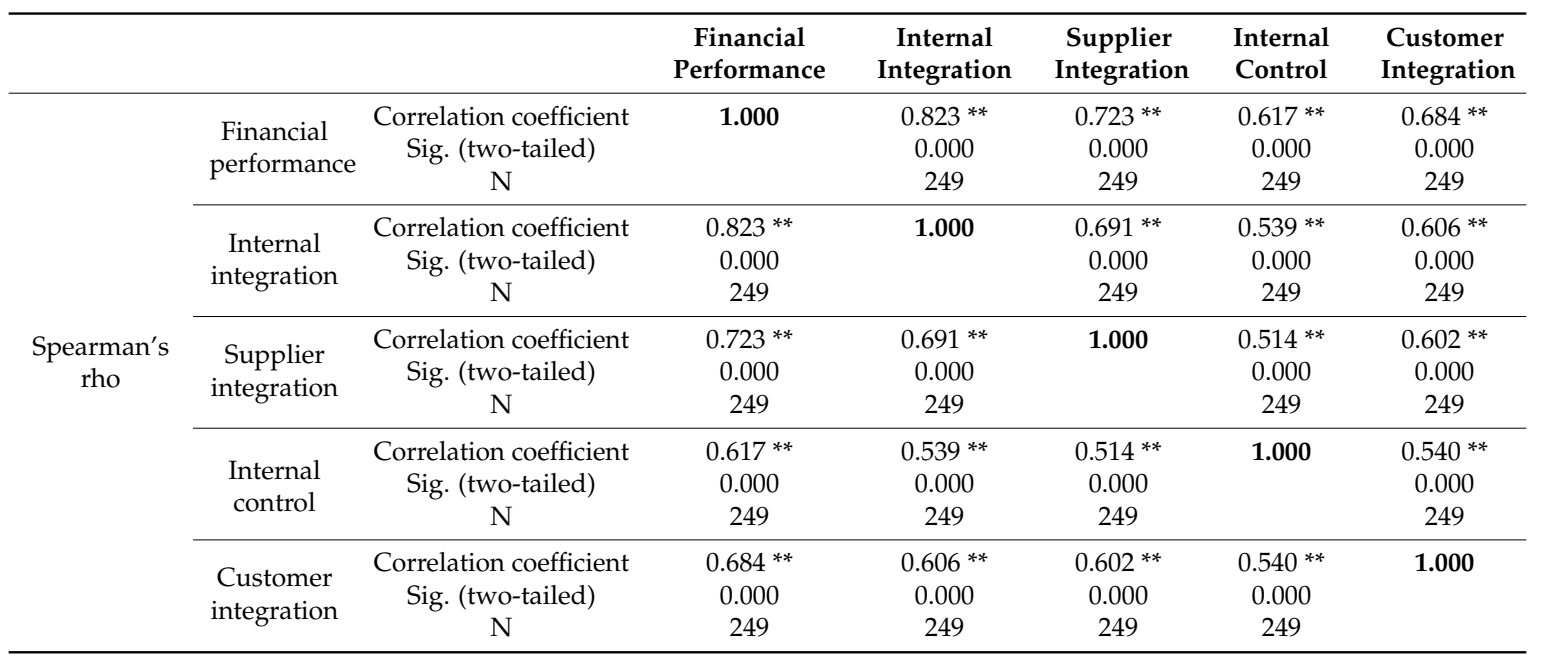

** Correlation is significant at the 0.01 level (two-tailed). Source: Authors' own editing, 2018.

\subsection{Discussion}

\subsubsection{The Impact of Supply Chain Integration on Financial Performance}

The findings emerging from hypotheses testing prove that there is a statistically significant impact of supply chain integration on financial performance. These results confirmed what earlier studies have found concerning the presence of the significant impact of supply chain integration on financial performance $[6,8,23,36,38,57]$.

\subsubsection{Customer Integration Influence on Financial Performance}

The results indicate that Jordanian banks depend on relationships with their customers to enhance and develop financial performance, and banks share knowledge with their customers. However, customer integration was the third most effective factor for financial performance, which means that internal integration and supplier integration affect financial performance more than customer integration. Our findings that customer integration is significantly related to financial performance are consistent with the findings of several previous studies $[8,44]$. The financial performance of banks in Jordan can be improved by linkage with customers through information networks, the evaluation of relationships with customers, collaborative planning, forecasting, and innovation, measurement of customer satisfaction, and taking future customer expectations into account.

\subsubsection{Supplier Integration Influence on Financial Performance}

The results shed light on the idea that supplier integration has a positive and significant impact on financial performance. Supplier integration was the second most effective factor related to the improvement of financial performance. Supplier integration may not contribute to financial performance directly; instead, it interacts with customer integration in improving financial performance, reflecting the importance of banks' integration with both downstream and upstream 
supply chain partners. In general, the literature on the relationship between supplier integration and performance has produced very mixed findings. While Koufteros et al. [27] found that supplier integration was negatively related to certain aspects of financial performance, Yu et al. [45] found a positive relationship between supplier integration and financial performance. Based on the developed model, the following items should be used to measure supplier integration: involvement beyond transactions, maintaining cooperative relationships, sharing plans, close communication, quick ordering systems, sharing schedules, information exchange, and helping improve the process of suppliers.

\subsubsection{Internal Integration Influence on Financial Performance}

The results show that internal integration has a positive and significant effect on financial performance. The results revealed that internal integration has the greatest impact on financial performance compared with other factors. The results indicated that Jordanian banking processes are integrated and connected with departments and employees through information sharing-depending on the relationship between departments-so as to effectively incorporate, enhance, and develop financial performance. Internal integration capabilities are the major drivers of a bank's financial performance. Internal integration plays a cornerstone role in enhancing the communication networks between employees and managerial levels. Accordingly, it will decrease the formality of the relationship between them, giving employees the sense of freedom to share different perspectives, opinions, and knowledge. In the same direction, decreasing the level of formality and removing boundaries between departments will encourage employees to suggest and share new ideas and changes as regards normal everyday business processes, which will be reflected in the efficiency and effectiveness of work, by decreasing work pressure and increasing employees' loyalty and motivation. Eventually, these elements will collectively contribute to enhancing an organization's overall financial performance. When we compare our results with those from previous research on supply chain integration, our finding that internal integration is significantly related to financial performance is consistent with several studies [6,15]. As an outcome of our analysis, the internal integration of Jordanian banks can be determined by collecting information about interdepartmental meetings, departments making decisions together, cooperation to solve conflicts, using performance metrics, helping so as to accomplish tasks efficiently, achieving goals jointly, working interactively, applying embedded internal controls, and the utilization of knowledge.

\subsubsection{The Impact of Internal Control on Financial Performance}

Internal control has a positive and significant effect on financial performance. Internal control implies sharing more knowledge with the board to help with evaluating and developing plans to achieve better financial performance. Internal control provides guidelines for managers that can help them direct their efforts so as to achieve superior performance.

The concept of internal control and the financial performance assessment process are closely linked. They complement each other. The goal is to identify gaps, and propose corrections and plans in the future so as to minimize risks and make the right decisions. These findings are consistent with previous studies that indicate the importance of internal control for enhanced financial performance [10,34].

To improve the efficiency of internal control, the most essential aspects are the following: impact on the flow of cash, information system integration and transparency, having responsibility, internal auditors' connection to the board, and teamwork.

The most important result of the study is that a tool was developed to measure the effect of integration on the performance of Jordanian banks. Factors related to customer integration, supplier integration, and internal integration were determined, as well as their importance. Our goal was to find ways to measure integration in banks' practices. It can be stated that the experiment is promising, and this exploratory research is one of the first steps for supply chain managers to develop tools that can be used in their daily work. 


\section{Conclusions}

The most commonly used dimensions of supply chain integration are customer integration, supplier integration, and internal integration. Questionnaires were constructed to measure the effect of these supply chain integration dimensions on financial performance. The aims of supply chain strategies can be accomplished by applying an efficient control system. Therefore, the model can be improved by adding a dimension of internal control to supply chain integration.

Originally, there were four factors in the supply chain integration model: customer integration, supplier integration, internal integration, and internal control. Our analysis proved that the four dimensions that were mentioned in the literature were subscales, but some of the items were eliminated, and others were moved to other groups of items. The four subscales that were proved by our analysis are appropriate tools for managers to measure supply chain integration. As an outcome of the factor analysis from the original questionnaire, which had 34 questions, seven items were eliminated, so that the subscales finally consisted of 27 items. As a result of the research, it can be stated that supply chain integration subscales, customer integration, supplier integration, internal integration, and internal control positively affect financial performance.

The importance of the subscales' effects on financial performance can be ranked in the following order: internal integration, supplier integration, customer integration, and internal control. The most important factors of internal integration are interdepartmental meetings, making decisions together, cooperating to solve conflicts, allocating proper costs for customers, helping with tasks, working jointly, being interactive, embedded internal controls, and the utilization of knowledge. Supplier integration can be improved by involvement beyond transactions, ameliorating cooperation, planning, communication, ordering, scheduling, information technology (IT) connections, and processes. There are many ways to develop customer integration such as using IT networks, evaluating relationships, planning together, predicting expectations, and evaluating satisfaction. Finally, the factors of improving internal control are control of cash flow, transparency, responsibility, and internal audits. The bank has embedded internal controls into a computerized system.

Finally, after examining how supply chain integration and internal control affect the performance of Jordanian banks, which was the most important result of our analysis, we found an appropriate measuring scale that could be used to measure these relationships. In an era in which supply chain integration is considered a cornerstone to achieve a sustainable competitive advantage, it is imperative for organizations to realize how to develop such integration. Supply chain integrations can be seen as a way to develop and maintain a competitive advantage, particularly with respect to the role of intra-organizational relationships and interactions among individuals and groups in facilitating, enhancing, and leveraging this process so as to achieve competitiveness. Moreover, the results indicated that internal integration is more strongly related to improving performance than supplier integration and customer integration.

\section{Recommendations}

Supplier integration, customer integration, and internal integration should be considered crucial factors in developing the financial performance of the Jordanian banking sector.

The order of the factors examined based on the correlation values is: internal integration $(r=0.823)$, supplier integration $(r=0.723)$, customer integration $(r=0.684)$, and internal control $(r=0.617)$, which can be considered by bank managers in order to develop the efficiency of their bank's financial performance.

The research suggests that Jordanian banks should pay more attention to internal control, as they have the greatest impact on financial performance, but supplier integration, customer integration, and internal control are also effective factors in bank management.

As a result of this study, we received a model with appropriate questions in the categories under review, which can be used as a measuring tool to assess the impact of internal integration, 
supplier integration, customer integration, and internal controls on the financial performance of Jordanian banks.

A limitation of the research is that the data collection was cross-sectional, but the processes exist in time; therefore, a periodical data collection could measure the changes over time. In addition, future research could be conducted to test the applicability of the findings of this research on other populations of different sizes in different countries to assess the generalizability of the findings.

Supplementary Materials: The following are available online at http:/ /www.mdpi.com/2071-1050/11/5/1248/ s1.

Author Contributions: J.O. and J.P. conceived and designed the experiments. M.P. and J.N. analyzed the data. M.P. and H.H. and J.O. contributed analysis tools. J.P. and H.H. wrote the paper.

Funding: This work was supported by EFOP3.6.3-VEKOP-16-2017-00007_“Young researchers for talent"- Supporting careers in research activities in higher education program.

Conflicts of Interest: The authors declare no conflict of interest.

\section{References}

1. Sroka, W.; Szántó, R. Corporate Social Responsibility and Business Ethics in Controversial Sectors: Analysis of Research Results. J. Entrep. Manag. Innov. 2018, 14, 111-126. [CrossRef]

2. Sroka, W.; VVeinhardt, J. Nepotism and favouritism in the steel industry: A case study analysis. Forum Sientiae Oecon. 2018, 6, 31-45.

3. Turkulainen, V.; Roh, J.; Whipple, J.M.; Swink, M. Managing Internal Supply Chain Integration: Integration Mechanisms and Requirements. J. Bus. Logist. 2017, 38, 290-309. [CrossRef]

4. Sweeney, E. Innovation for Competing in Highly Competitive Markets in Supply Chain Innovation for Competing in Highly Competitive Markets: Challenges and Solutions; National Institute of Transport and Logistics: Dublin, Ireland, 2012.

5. Oláh, J.; Karmazin, G.; Pető, K.; Popp, J. Information technology developments of logistics service providers in Hungary. Int. J. Logist. Res. Appl. 2018, 21, 332-344. [CrossRef]

6. Flynn, B.B.; Huo, B.; Zhao, X. The impact of supply chain integration on performance: A contingency and configuration approach. J. Oper. Manag. 2010, 28, 58-71. [CrossRef]

7. Kot, S. Sustainable Supply Chain Management in Small and Medium Enterprises. Sustainability 2018, 10, 1143. [CrossRef]

8. Schoenherr, T.; Swink, M. Revisiting the arcs of integration: Cross-validations and extensions. J. Oper. Manag. 2012, 30, 99-115. [CrossRef]

9. Ataseven, C.; Nair, A. Assessment of supply chain integration and performance relationships: A meta-analytic investigation of the literature. Int. J. Prod. Econ. 2017, 185, 252-265. [CrossRef]

10. Haddad, H. Internal Controls in Jordanian Banks and Compliance Risk. Res. J. Financ. Acc. 2016, 7, 17-31.

11. Lutz, J. Committee of Sponsoring Organizations of the Treadway Commission: Internal Control; Integrated Framework Mit Besonderer Berücksichtigung der Änderungen in der Neuauflage 2013. Master's Thesis, Hochschule Mittweida, Mittweida, Germany, 2015.

12. De Souza Miguel, P.L.; Brito, L.A.L. Supply Chain Management measurement and its influence on Operational Performance. J. Oper. Suppl. Chain Manag. 2011, 4, 56-70. [CrossRef]

13. Abdallah, A.B.; Obeidat, B.Y.; Aqqad, N.O. The impact of supply chain management practices on supply chain performance in Jordan: The moderating effect of competitive intensity. Int. Bus. Res. 2014, 7, 13. [CrossRef]

14. Jabbour, A.B.L.; Filho, A.G.A.; Viana, A.B.N.; Jabbour, C.J.C. Measuring supply chain management practices. Meas. Bus. Excell. 2011, 15, 18-31. [CrossRef]

15. Lotfi, Z.; Mukhtar, M.; Sahran, S.; Zadeh, A.T. Information sharing in supply chain management. Procedia Technol. 2013, 11, 298-304. [CrossRef]

16. Wong, C.W.; Wong, C.Y.; Boon-itt, S. The combined effects of internal and external supply chain integration on product innovation. Int. J. Prod. Econ. 2013, 146, 566-574. [CrossRef]

17. Slusarczyk, B.; Smolag, K.; Kot, S. The Supply Chain of a Tourism Product. Actual Probl. Econ. 2016, 197-207. Available online: http:/ / nbuv.gov.ua/UJRN/ape_2016_5_23 (accessed on 26 February 2019). 
18. Lii, P.; Kuo, F.-I. Innovation-oriented supply chain integration for combined competitiveness and firm performance. Int. J. Prod. Econ. 2016, 174, 142-155. [CrossRef]

19. Qi, Y.; Huo, B.; Wang, Z.; Yeung, H.Y.J. The impact of operations and supply chain strategies on integration and performance. Int. J. Prod. Econ. 2017, 185, 162-174. [CrossRef]

20. Ince, H.; Imamoglu, S.Z.; Keskin, H.; Akgun, A.; Efe, M.N. The impact of ERP systems and supply chain management practices on firm performance: Case of Turkish companies. Procedia-Soc. Behav. Sci. 2013, 99, 1124-1133. [CrossRef]

21. Silvestro, R.; Lustrato, P. Integrating financial and physical supply chains: The role of banks in enabling supply chain integration. Int. J. Oper. Prod. Manag. 2014, 34, 298-324. [CrossRef]

22. Yang, C.-C.; Wei, H.-H. The effect of supply chain security management on security performance in container shipping operations. Suppl. Chain Manag. Int. J. 2013, 18, 74-85. [CrossRef]

23. Kim, D.-Y. Relationship between supply chain integration and performance. Oper. Manag. Res. 2013, 6, 74-90. [CrossRef]

24. Danese, P. Supplier integration and company performance: A configurational view. Omega 2013, 41, 1029-1041. [CrossRef]

25. Oláh, J.; Bai, A.; Karmazin, G.; Balogh, P.; Popp, J. The role played by trust and its effect on the competiveness of logistics service Providers in Hungary. Sustainability 2017, 9, 2303. [CrossRef]

26. Lau, A.K.; Yam, R.C.; Tang, E.P. Supply chain integration and product modularity: An empirical study of product performance for selected Hong Kong manufacturing industries. Int. J. Oper. Prod. Manag. 2010, 30, 20-56. [CrossRef]

27. Koufteros, X.; Verghese, A.J.; Lucianetti, L. The effect of performance measurement systems on firm performance: A cross-sectional and a longitudinal study. J. Oper. Manag. 2014, 32, 313-336. [CrossRef]

28. Narasimhan, R.; Narayanan, S.; Srinivasan, R. Explicating the mediating role of integrative supply management practices in strategic outsourcing: A case study analysis. Int. J. Prod. Res. 2010, 48, 379-404. [CrossRef]

29. Kotcharin, S.; Eldridge, S.; Freeman, J. Investigating the relationships between internal integration and external integration and their impact on combinative competitive capabilities. In Proceedings of the 17th International Working Seminar on Production Economics, Innsbruck, Austria, 20-24 February 2012; pp. 1-12.

30. Ayoub, H.F.; Abdallah, A.B.; Suifan, T.S. The effect of supply chain integration on technical innovation in Jordan: The mediating role of knowledge management. Benchmarking 2017, 24, 594-616. [CrossRef]

31. Länsiluoto, A.; Jokipii, A.; Eklund, T. Internal control effectiveness-a clustering approach. Manag. Audit. J. 2016, 31, 5-34. [CrossRef]

32. Pallant, J. SPSS Survival Manual, 2nd ed.; Open University Press: Berkshire, UK, 2005.

33. Ayagre, P.; Appiah-Gyamerah, I.; Nartey, J. The effectiveness of Internal Control Systems of banks. The case of Ghanaian banks. Int. J. Acc. Financ. Rep. 2014, 4, 377-389. [CrossRef]

34. IIA Institute of Internal Auditors: Lake Mary, USA. 2013. Available online: https://global.theiia.org/Pages/ globaliiaHome.aspx (accessed on 26 February 2019).

35. Wheelen, T.L.; Hunger, J.D.; Hoffman, A.N.; Bamford, C.E. Strategic Management and Business Policy: Toward Global Sustainability; Pearson Education Inc.: London, UK, 2017; ISBN 978-0132153225.

36. Huo, B. The impact of supply chain integration on company performance: An organizational capability perspective. Suppl. Chain Manag. Int. J. 2012, 17, 596-610. [CrossRef]

37. Appiah-Adu, K. Market orientation and performance: Empirical tests in a transition economy. J. Strateg. Mark. 1998, 6, 25-45. [CrossRef]

38. Jitpaiboon, T.; Dobrzykowski, D.D.; Ragu-Nathan, T.; Vonderembse, M.A. Unpacking IT use and integration for mass customisation: A service-dominant logic view. Int. J. Prod. Res. 2013, 51, 2527-2547. [CrossRef]

39. Chang, W.; Ellinger, A.E.; Kim, K.K.; Franke, G.R. Supply chain integration and firm financial performance: A meta-analysis of positional advantage mediation and moderating factors. Eur. Manag. J. 2016, 34, $282-295$. [CrossRef]

40. Mafini, C.; Pooe, D.R. The relationship between employee satisfaction and organisational performance: Evidence from a South African government department. SA J. Ind. Psychol. 2013, 39. [CrossRef]

41. Mele, C.; Russo Spena, T.; Colurcio, M. Co-creating value innovation through resource integration. Int. J. Qual. Serv. Sci. 2010, 2, 60-78. [CrossRef] 
42. Zhao, X.; Huo, B.; Selen, W.; Yeung, J.H.Y. The impact of internal integration and relationship commitment on external integration. J. Oper. Manag. 2011, 29, 17-32. [CrossRef]

43. Kliestik, T.; Misankova, M.; Valaskova, K.; Svabova, L. Bankruptcy Prevention: New Effort to Reflect on Legal and Social Changes. Sci. Eng. Ethics 2018, 24, 791-803. [CrossRef] [PubMed]

44. Zhang, C.; Gunasekaran, A.; Wang, W.Y.C. A comprehensive model for supply chain integration. Benchmarking 2015, 22, 1141-1157. [CrossRef]

45. Yu, W.; Jacobs, M.A.; Salisbury, W.D.; Enns, H. The effects of supply chain integration on customer satisfaction and financial performance: An organizational learning perspective. Int. J. Prod. Econ. 2013, 146, 346-358. [CrossRef]

46. Msimangira, K.A.; Venkatraman, S. Supply chain management integration: Critical problems and solutions. Oper. Suppl. Chain Manag. 2014, 7, 23-31. [CrossRef]

47. Demeter, K.; Szász, L.; Rácz, B.-G. The impact of subsidiaries' internal and external integration on operational performance. Int. J. Prod. Econ. 2016, 182, 73-85. [CrossRef]

48. Kliestik, T.; Kovacova, M.; Podhorska, I.; Kliestikova, J. Searching for key sources of goodwill creation as new global managerial challenge. Pol. J. Manag. Stud. 2018, 17, 144-154. [CrossRef]

49. Hannah, N. The Effect of Internal Controls on Revenue Generation: A Case Study of the University of Nairobi Enterprise and Services Limited. Master's Thesis, University of Nairobi, Nairobi, Kenya, 2013.

50. Brunswicker, S.; Chesbrough, H. The Adoption of Open Innovation in Large Firms: Practices, Measures, and Risks A survey of large firms examines how firms approach open innovation strategically and manage knowledge flows at the project level. Res. Technol. Manag. 2018, 61, 35-45. [CrossRef]

51. Werner, M.; Gehrke, N. Identifying the Absence of Effective Internal Controls-An Alternative Approach for Internal Control Audits. J. Inf. Syst. 2018. [CrossRef]

52. Carnes, R.R.; Christensen, D.M.; Lamoreaux, P.T. Investor Demand for Internal Control Audits of Large US Companies: Evidence from a Regulatory Exemption for M\&A Transactions. Acc. Rev. 2018. [CrossRef]

53. Cheng, B.-L. Service quality and the mediating effect of corporate image on the relationship between customer satisfaction and customer loyalty in the Malaysian hotel industry. Gadjah Mada Int. J. Bus. 2013, 15, 99-112. [CrossRef]

54. Sekaran, U.; Bougie, R. Research Methods for Business: A Skill Building Approach; John Wiley \& Sons: Hoboken, NJ, USA, 2016; p. 1119165555.

55. Garson, D.G. Factor Analysis: Statnotes. 2008. Available online: https://www.encorewiki.org/download/ attachments / 25657 / Factor+Analysis_+Statnotes+from+North+Carolina+State+University.pdf (accessed on 27 February 2019).

56. Nunnally, J. Psychometric Theory; McGraw-Hill: New York, NY, USA, 1978.

57. Richey, R.G., Jr.; Roath, A.S.; Whipple, J.M.; Fawcett, S.E. Exploring a governance theory of supply chain management: Barriers and facilitators to integration. J. Bus. Logist. 2010, 31, 237-256. [CrossRef] 